\title{
Characterization of the BFO-BZN-based electroceramic composite for application as DRA
}

\section{(Caracterização do compósito eletrocerâmico baseado em BFO-BZN para aplicação como DRA)}

\author{
A. V. Duarte ${ }^{1}$, E. C. L. da Silva ${ }^{1}$, E. A. O. Melo ${ }^{1}$, F. M. M. Pereira ${ }^{1 *}$, A. S. B. Sombra ${ }^{2}$ \\ ${ }^{1}$ Universidade Federal do Cariri, Av. Ten. Raimundo Rocha 1639, 63048-080, Juazeiro do Norte, CE, Brazil \\ ${ }^{2}$ Universidade Federal do Ceará, Laboratório de Telecomunicações e Ciência e \\ Engenharia de Materiais, Fortaleza, CE, Brazil
}

\begin{abstract}
The study and development of ceramic composites are important because of the properties that these materials can provide, such as high dielectric constant and low dielectric loss in the RF and microwave range. Such characteristics make this type of material appropriate to several segments, such as in the telecommunication sector, especially in dielectric resonator antenna (DRA). Ceramic composites provide new materials with a range of properties that can be controlled through the phases to meet the specifications of a given application. This study aimed to synthesize and characterize the composite based on hexaferrite (BFO) and ceramics based on bismuth (BZN), aiming application as DRA. The composites were characterized by FTIR, XRD, and SEM. The composites presented a compact and heterogeneous microstructure, indicating that the sintering at $1000{ }^{\circ} \mathrm{C} / 150$ min was adequate for obtaining the ceramic composites; besides, BFO-BZN $\beta$ composite was shown to be less porous than the composite BFO-BZN $\alpha$.
\end{abstract}

Keywords: ceramic composites, hexaferrite, BZN, DRA.

Resumo

O estudo e desenvolvimento de compósitos cerâmicos possui elevada importância devido às propriedades que esses materiais podem fornecer, tais como elevada constante dielétrica e baixa perda dielétrica na faixa de RF e micro-ondas. Tais características tornam esse tipo de material aplicável a diversos segmentos, como no setor de telecomunicações, em especial em antena dielétrica ressonadora (DRA). Compósitos cerâmicos fornecem novos materiais com uma gama de propriedades que podem ser controladas através das fases para atender as especificações de uma determinada aplicação. Esse estudo teve como objetivo sintetizar e caracterizar o compósito baseado em hexaferrita (BFO) e cerâmicas à base de bismuto (BZN) visando aplicação como DRA. Os compósitos foram caracterizados por FTIR, DRX e MEV. Os compósitos apresentaram microestrutura compacta e heterogênea, indicando que a sinterização em $1000{ }^{\circ} \mathrm{C} / 150 \mathrm{~min}$ foi adequada para obtenção dos compósitos cerâmicos, sendo o que compósito BFO-BZN $\beta$ se mostrou menos poroso que o compósito BFO-BZN $\alpha$.

Palavras-chave: compósitos cerâmicos, hexaferrita, $B Z N, D R A$.

\section{INTRODUCTION}

The rapid growth of satellite and mobile radio communications has led to a requirement for narrowband, frequency-stable filters and oscillators. Selectivity and stability are necessary to ensure that signals are confined to closely defined allotted frequency bands and to prevent the intrusion of unwanted signals which would interfere with the satisfactory performance of the system. Antennae are also critical components of any wireless communications system. The need for compactness in satellite and hand-held mobile systems is self-evident [1]. The solution to providing stable filters and oscillators in the past lay in bulky coaxial and cavity resonators fabricated from the temperature-stable

*francisca.martins@ufca.edu.br

Dhttps://orcid.org/0000-0002-8477-8922 metal alloy Invar. The dielectric resonator (DR) offers a means of miniaturizing the device. In its simplest form a DR is a cylinder of ceramic of relative permittivity $\varepsilon_{\mathrm{r}}$ sufficiently high for standing electromagnetic wave to be sustained within its volume because of reflection at the dielectric-air interface [1].

The development of ceramic composites for wireless transmission systems applications has been a subject of research and discussions in technological institutes, universities, and companies. The increasing demand for solutions for this branch of the telecommunications sector, which involves low energy consumption, minimization of component dimensions and cost reduction, has led to an interest in ceramic composites [2]. Ceramic composites are attractive for telecommunications because of the flexibility of features that can be obtained by the mixture of two or more phases, providing new materials with a wide 
range of properties (mechanical, magnetic, optical and dielectric properties) that can be controlled through phase composition to meet the desired specifications necessary for a particular application. There are several applications such as capacitors, substrates for encapsulation of electronic circuits, antennas, sensors, high voltage insulation, and fuel cells $[3,4]$.

The increasing development of composites associated with the propagation of signals in the microwave range allows the use of these materials in wireless applications and in the design of antennas. For the construction of these composites, the ferrites are important because of their applications in telecommunications and electronic devices, while the bismuth-based ceramics are suitable for the application of antennas due to their relatively high dielectric constant and low dielectric loss in the RF and microwave range $[2,5,6]$. A combined study of both the crystal structure and the electrophysical properties of new compounds and solid solutions is necessary for the development of new ceramic materials. A refinement of stoichiometric compositions and homogeneity regions of new materials is desirable [7]. The objective of this study was to prepare and characterize the electroceramic composite based on hexaferrite and ceramics based on bismuth, aiming application as a dielectric resonator antenna (DRA).

\section{EXPERIMENTAL}

Synthesis of BFO-BZN electroceramic composites: the oxides $\mathrm{Fe}_{2} \mathrm{O}_{3}, \mathrm{Bi}_{2} \mathrm{O}_{3}, \mathrm{ZnO}, \mathrm{Nb}_{2} \mathrm{O}_{5}$, and carbonate $\mathrm{BaCO}_{3}$ used in the synthesis of the BFO and BZN phases were analytical grade reagents with high purity (Sigma-Aldrich). The BFO and BZN phases were prepared separately, where the precursor reactants were weighed in stoichiometric amounts, milled in a planetary mill (Fritsch, Pulverisette 6) at a speed of $370 \mathrm{rpm}$, using $10 \mathrm{~mm}$ diameter stainless steel beads. After obtaining the ceramic powders, they were calcined in a muffle furnace (Jung, LF0614) at $1000{ }^{\circ} \mathrm{C} / 24 \mathrm{~h}$ $\left(\mathrm{BaFe}_{12} \mathrm{O}_{19}-\mathrm{BFO}\right)$ or $700{ }^{\circ} \mathrm{C} / 2 \mathrm{~h}\left(\mathrm{Bi}_{1.5} \mathrm{ZnNb}_{1.5} \mathrm{O}_{7}-\alpha-\mathrm{BZN}\right.$, and $\mathrm{Bi}_{2} \mathrm{Zn}_{2 / 3} \mathrm{Nb}_{4 / 3} \mathrm{O}_{7}-\beta$-BZN) in ar. The reactions that occurred during calcination were $[8,9]$ :

$$
\begin{aligned}
& \mathrm{BaCO}_{3}(\mathrm{~s})+6 \mathrm{Fe}_{2} \mathrm{O}_{3}(\mathrm{~s}) \rightarrow \mathrm{BaFe}_{12} \mathrm{O}_{19}(\mathrm{~s})+\mathrm{CO}_{2}(\mathrm{~g}) \\
& 0.75 \mathrm{Bi}_{2} \mathrm{O}_{3}(\mathrm{~s})+\mathrm{ZnO}(\mathrm{s})+0.75 \mathrm{Nb}_{2} \mathrm{O}_{5}(\mathrm{~s}) \rightarrow \\
& \mathrm{Bi}_{1.5} \mathrm{ZnNb}_{1.5} \mathrm{O}_{7}(\mathrm{~s}) \\
& \mathrm{Bi}_{2} \mathrm{O}_{3}(\mathrm{~s})+0.67 \mathrm{ZnO}(\mathrm{s})+1.3 \mathrm{Nb}_{2} \mathrm{O}_{5}(\mathrm{~s}) \rightarrow \\
& \mathrm{Bi}_{2} \mathrm{Zn}_{0.67} \mathrm{Nb}_{1.33} \mathrm{O}_{7}(\mathrm{~s})
\end{aligned}
$$

The obtained BFO and BZN ceramic powders were weighed stoichiometrically, milled in a planetary mill (Fritsch, Pulverisette 6) for $10 \mathrm{~min}$. Then the mixture of these materials was uniaxially disc-shaped, sintered at $1000{ }^{\circ} \mathrm{C}$ for $150 \mathrm{~min}$. The samples were named according to the concentration of hexaferrite $\mathrm{BaFe}_{12} \mathrm{O}_{19}(\mathrm{BFO})$ present in the composites: $(\mathrm{BFO})_{\mathrm{y}}+(\alpha-\mathrm{BZN})_{1-\mathrm{y}}$ and $(\mathrm{BFO})_{\mathrm{y}}+(\beta-\mathrm{BZN})_{1-\mathrm{y}}$ (Table I).

Characterization of BFO-BZN electroceramic composites. Fourier-transform infrared (FTIR) spectroscopy: the analyzes were performed in an FTIR spectrometer (Bruker, Vertex 70v) using the attenuated total reflectance (ATR) accessory. Spectra were obtained in the transmission mode with $\mathrm{KBr}$ pellets in the range of 130 to $4000 \mathrm{~cm}^{-1}$ with a resolution of $4 \mathrm{~cm}^{-1}$. X-ray diffraction $(X R D)$ : the diffractograms of the sintered discs at $1000{ }^{\circ} \mathrm{C} / 50$ min of the ceramic composites were obtained in a diffractometer (Rigaku, Dmax-B), configured in a BraggBrentano type geometry, using $\mathrm{CuK} \alpha$ radiation $(40 \mathrm{kV}$ and $25 \mathrm{~mA}, \lambda=0.15442 \mathrm{~nm}$ ). The angular range in $2 \theta$ was $20^{\circ}-80^{\circ}$ with a velocity of $0.5 \% \mathrm{~min}$. Scanning electron microscopy (SEM): the analyzes to evaluate the morphology of the ceramic composites were performed in a scanning electron microscope (Tecscan, Vega II XMU) operating at $5 \mathrm{~mA}$ and $50 \mathrm{kV}$. The sintered samples were bonded onto a metal plate with silver conductive paint (Joint Metal, PC200) and coated with a gold layer (Bal-Tec, MED 020), approximately $30 \mathrm{~nm}$ thickness, for SEM analysis.

Table I - Nomenclature of composite samples $\left(\mathrm{BaFe}_{12} \mathrm{O}_{19}\right)_{\mathrm{y}}+\left(\mathrm{Bi}_{1.5} \mathrm{ZnNb}_{1.5} \mathrm{O}_{7}\right)_{1-\mathrm{y}}$ and $\left(\mathrm{BaFe}_{12} \mathrm{O}_{19}\right)_{\mathrm{y}}+\left(\mathrm{Bi}_{2} \mathrm{Zn}_{2 / 3} \mathrm{Nb}_{4 / 3} \mathrm{O}_{7}\right)_{1-\mathrm{y}}$.

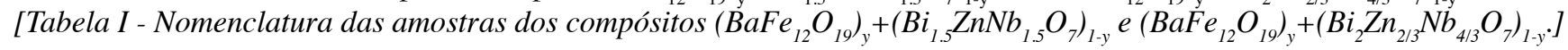

\begin{tabular}{ccc}
\hline Sample & $\mathrm{BaFe}_{12} \mathrm{O}_{19}-\mathrm{BFO}(\%)$ & Nomenclature \\
\hline $\mathrm{Bi}_{1.5} \mathrm{ZnNb}_{1.5} \mathrm{O}_{7}$ & 0 & $\mathrm{BZN} \alpha$ \\
$\left(\mathrm{BaFe}_{12} \mathrm{O}_{19}\right)_{0.25}+\left(\mathrm{Bi}_{1.5} \mathrm{ZnNb}_{1.5} \mathrm{O}_{7}\right)_{0.75}$ & 25 & $\mathrm{BZN} \alpha 25$ \\
$\left(\mathrm{BaFe}_{12} \mathrm{O}_{19}\right)_{0.50}+\left(\mathrm{Bi}_{1.5} \mathrm{ZnNb}_{1.5} \mathrm{O}_{7}\right)_{0.50}$ & 50 & $\mathrm{BZN} \alpha 50$ \\
$\left(\mathrm{BaFe}_{12} \mathrm{O}_{19}\right)_{0.75}+\left(\mathrm{Bi}_{1.5} \mathrm{ZnNb}_{1.5} \mathrm{O}_{7}\right)_{0.25}$ & 75 & $\mathrm{BZN} \alpha 75$ \\
$\mathrm{Bi}_{2} \mathrm{Zn}_{0.67} \mathrm{Nb}_{1.33} \mathrm{O}_{7}$ & 0 & $\mathrm{BZN} \beta$ \\
$\left(\mathrm{BaFe}_{12} \mathrm{O}_{19}\right)_{0.55}+\left(\mathrm{Bi}_{2} \mathrm{Zn}_{0.67} \mathrm{Nb}_{1.33} \mathrm{O}_{7}\right)_{0.75}$ & 25 & $\mathrm{BZN} \beta 25$ \\
$\left(\mathrm{BaFe}_{12} \mathrm{O}_{19}\right)_{0.50}+\left(\mathrm{Bi}_{2} \mathrm{Zn}_{0.67} \mathrm{Nb}_{1.33} \mathrm{O}_{7}\right)_{0.50}$ & 50 & $\mathrm{BZN} \beta 50$ \\
$\left(\mathrm{BaFe}_{12} \mathrm{O}_{19}\right)_{0.75}+\left(\mathrm{Bi}_{2} \mathrm{Zn}_{0.67} \mathrm{Nb}_{1.33} \mathrm{O}_{7}\right)_{0.25}$ & 75 & $\mathrm{BZN} \beta 75$ \\
$\mathrm{BaFe}_{12} \mathrm{O}_{19}$ & 100 & $\mathrm{BFO}$ \\
\hline
\end{tabular}




\section{RESULTS AND DISCUSSION}

Fourier-transform infrared (FTIR) spectroscopy: the FTIR spectra of the BFO-BZN $\alpha$ and BFO-BZN $\beta$ ceramic composites are shown in Figs. $1 \mathrm{a}$ and $1 \mathrm{~b}$, respectively. Although hexaferrites are well-known, few studies have been reported on vibrational spectroscopy of barium hexaferrite $\left(\mathrm{BaFe}_{12} \mathrm{O}_{19}\right)$ [10], because ionic materials such as $\mathrm{Fe}^{3+}$ oxide have the active modes in the infrared with vibrations of the crystalline lattice involving the participation of all atoms. In addition, it is important to note that the absorption frequencies, as well as the intensity of the bands in the FTIR, may vary as a function of the particle size, shape, and state of aggregation. It was observed that the frequencies, as well as band intensities, varied significantly as a function of particle size and/or volume of the $\mathrm{BaFe}_{12} \mathrm{O}_{19}$ crystallite fraction in the glass [11]. The bands located at 2237 and $\sim 327 \mathrm{~cm}^{-1}$ in the spectrum of the BFO sample can be attributed to the vibrations of the oxygen ions of the spinel block (block S) [12], since the two modes associated with the vibration of the spinel-block oxygen ions are expected in the $300-100 \mathrm{~cm}^{-1}$ range. The band located at $\sim 387 \mathrm{~cm}^{-1}$ was attributed to the angular deformation of the $\mathrm{Fe}-\mathrm{O}$ bond in the tetrahedron, and that located at $\sim 415 \mathrm{~cm}^{-1}$ was attributed to the stretching of the Fe-O bond in the octahedrons, and the band at $538 \mathrm{~cm}^{-1}$ was attributed to the angular deformation of the $\mathrm{Ba}-\mathrm{O}$ bond, thus indicating the formation of the hexaferrite $\mathrm{BaFe}_{12} \mathrm{O}_{19}$ (BFO) [13-17]. As can be seen in Fig. 1, the FTIR spectra of the samples BZN $\alpha$ e BZN $\beta$, as well as the composites, showed no significant differences. The absorption bands observed at 469 and $328 \mathrm{~cm}^{-1}$ were attributed to the stretching of the metal-oxygen bond in the sample BZN $\alpha$, and the bands at $601,515,447$ and $328 \mathrm{~cm}^{-1}$ were attributed to the stretching of the metal-oxygen bond in the sample BZN $\beta$ [18-21]. Pyrochlore oxides with different cations at site A or B may appear as distinct configurations because the exact positions of the atoms may change slightly [22]. The absorption bands at about 300 and $400 \mathrm{~cm}^{-1}$ are shown as A-O elongation vibration modes in the $\mathrm{AO}_{6} \mathrm{O}_{2}$ polyhedron [23].

$X$-ray diffraction $(X R D)$ : Figs. $2 \mathrm{a}$ and $2 \mathrm{~b}$ show the $\mathrm{XRD}$ patterns of the ceramic composites BFO-BZN $\alpha$ and BFO$\mathrm{BZN} \beta$, respectively, sintered at $1000{ }^{\circ} \mathrm{C} / 150 \mathrm{~min}$. The XRD data of the BFO sample showed a predominance of the magnetoplumbite structure $\mathrm{BaFe}_{12} \mathrm{O}_{19}$, with the $\mathrm{P} 6 / \mathrm{mmc}$ space group, hexagonal symmetry, as evidenced by the highest intensities of peaks between $30^{\circ}$ and $40^{\circ}$ (hkl $=107$ and 114). All peaks were in-line with the diffraction pattern ICSD PDF 84-0757. XRD pattern of BZN $\alpha$ sample showed the formation of the $\alpha$-BZN $\left(\mathrm{Bi}_{1.5} \mathrm{ZnNb}_{1.5} \mathrm{O}_{7}\right)$ phase with space group $\mathrm{Fd} 3 \mathrm{~m}, \alpha=\beta=\gamma=90^{\circ}$, $\mathrm{a}=\mathrm{b}=\mathrm{c}=10.557 \AA$, density of $7.044 \mathrm{~g} / \mathrm{cm}^{3}$ and unit cell volume of $1176.6 \AA^{3}$, which conformed to the standard ICSD PDF 00-052-1770, and also the formation of a small amount of the phases $\mathrm{BiNbO}_{4}$ (ICSD PDF 00-016-0295) and ZnO (ICSD PDF 00-0030752) [8]. These remaining phases were precursor phases of $\alpha$-BZN, according to the reaction indicated in Eq. D [24]. That was completed at around $800^{\circ} \mathrm{C}$ for a time of $300 \mathrm{~min}$. As the reaction is diffusional, at higher temperatures, smaller reaction times are required, therefore, at $1000^{\circ} \mathrm{C}$ an almost pure $\alpha-\mathrm{BZN}$ phase was obtained, even for short sintering time [7].

$$
\mathrm{BiNbO}_{4}+\mathrm{ZnO} \rightarrow \alpha-\mathrm{BZN}
$$

XRD pattern of BZN $\beta$ sample showed the formation of $\beta$-BZN $\left(\mathrm{Bi}_{2} \mathrm{Zn}_{2 / 3} \mathrm{Nb}_{4 / 3} \mathrm{O}_{7}\right)$ phase with the $\mathrm{C} 2 / \mathrm{c}$ space group, $\alpha=\gamma=90.0^{\circ}, \beta=101.256^{\circ}, a=13.119 \AA, b=7.671 \AA, c=12.165$ $\AA$, density of $7.719 \mathrm{~g} / \mathrm{cm}^{3}$, and volume of the unit cell of $1200.7 \AA^{3}$, which were in accordance with the ICSD standard PDF 00-052-0141, and two remaining phases, $\mathrm{Bi}_{5} \mathrm{Nb}_{3} \mathrm{O}_{15}$ (ICSD PDF 00-016-0293) and $\mathrm{BiNbO}_{4}$ (ICSD PDF 01-071-1518), following the reaction path shown in Eq. $\mathrm{E}$ [8]. At $700{ }^{\circ} \mathrm{C}$ the time required for complete formation of $\beta$-BZN is quite high, partially observing its formation and the presence of remaining phases; with increasing
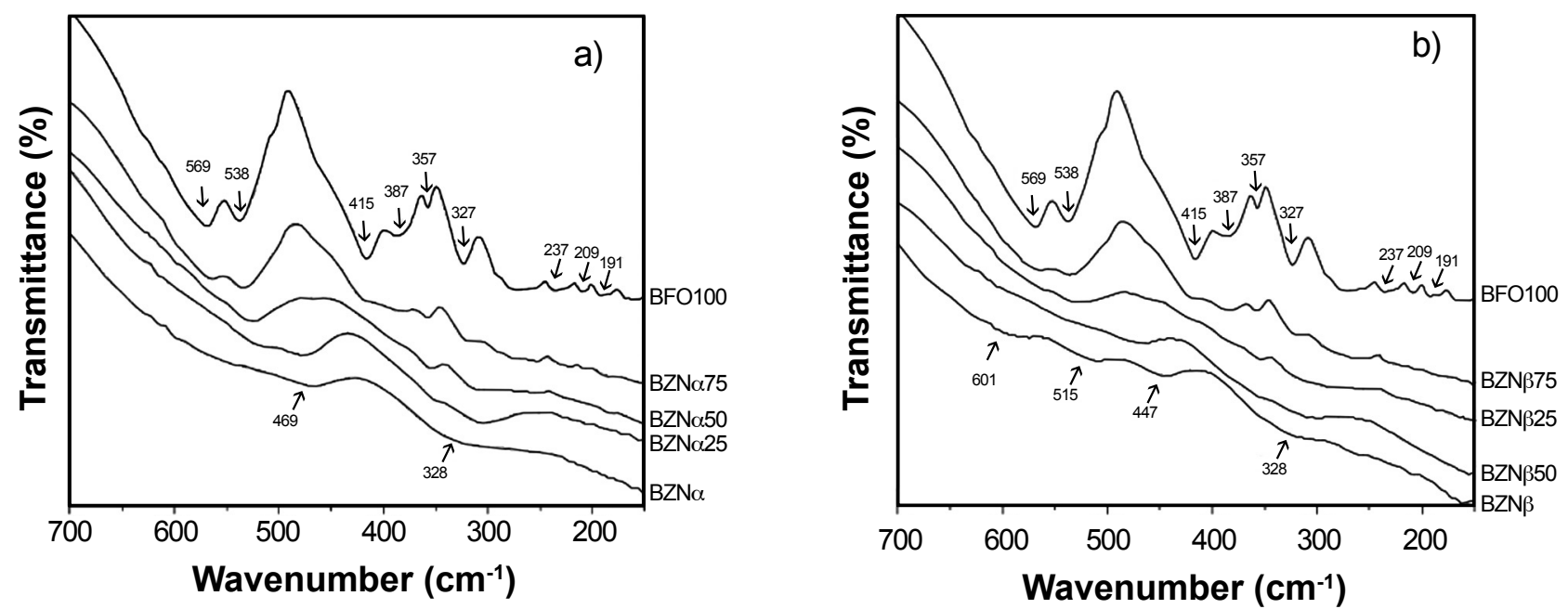

Figure 1: FTIR spectra of BFO-BZN $\alpha$ (a) and BFO-BZN $\beta$ (b) ceramic composites sintered at $1000{ }^{\circ} \mathrm{C} / 150 \mathrm{~min}$.

[Figura 1: Espectros de FTIR dos compósitos cerâmicos BFO-BZNa (a) e BFO-BZN $\beta$ (b) sinterizados a $1000^{\circ} \mathrm{C} / 150 \mathrm{~min}$.] 

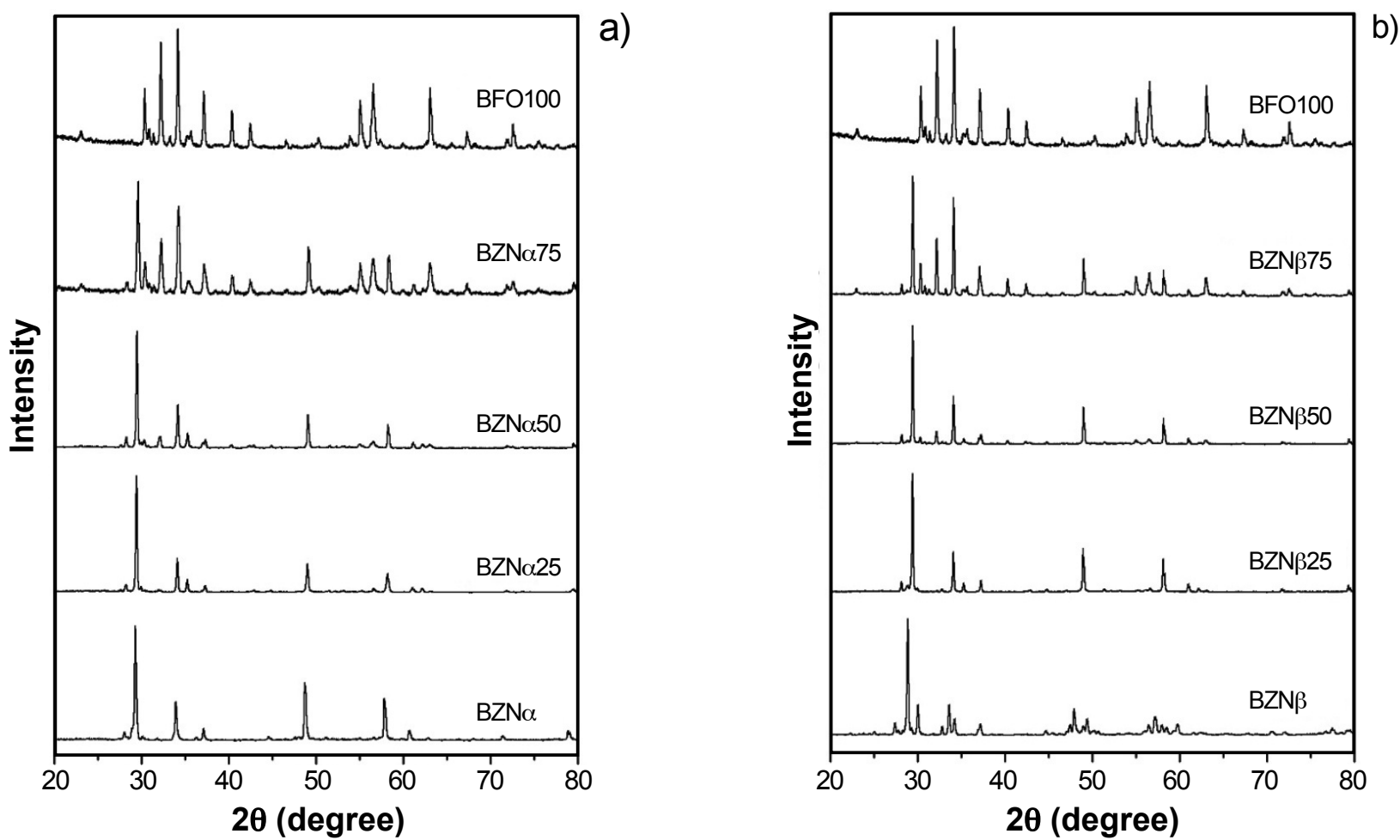

Figure 2: XRD patterns of the BFO-BZN $\alpha$ (a) and BFO-BZN $\beta$ (b) ceramic composites sintered at $1000{ }^{\circ} \mathrm{C} / 150 \mathrm{~min}$.

[Figura 2: Padrões de DRX dos compósitos cerâmicos BFO-BZNa (a) e BFO-BZN $\beta$ (b) sinterizados a $1000{ }^{\circ} \mathrm{C} / 150 \mathrm{~min}$.]
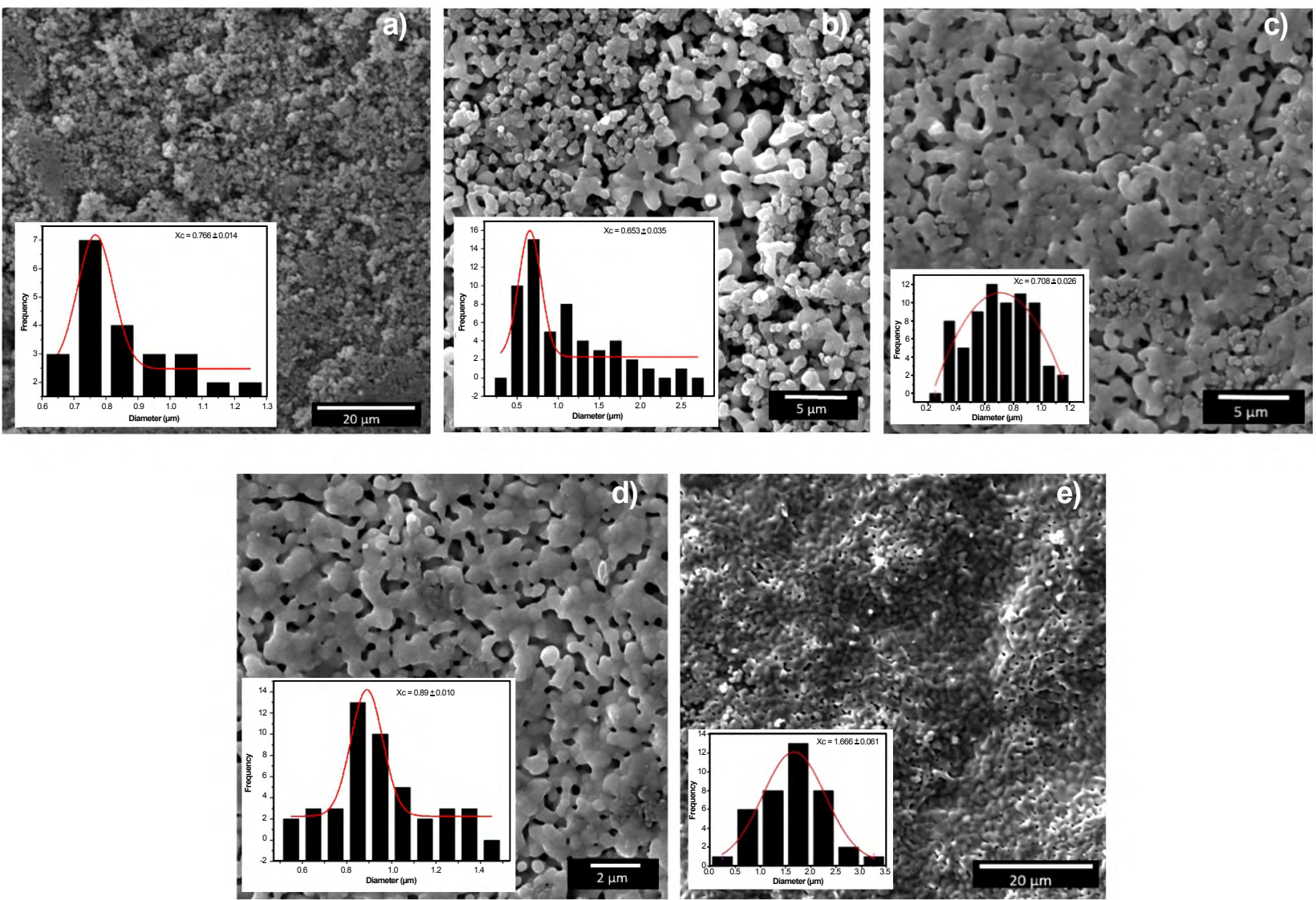

Figure 3: SEM micrographs of the BFO-BZNa ceramic composites sintered at $1000{ }^{\circ} \mathrm{C} / 150$ min: a) BFO; b) BZNa75; c) BZNa50; d) $\mathrm{BZN} \alpha 25$; e) BZN $\alpha$.

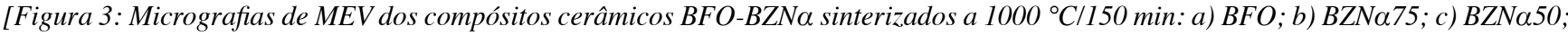
d) BZNa25; e) BZNa.] 

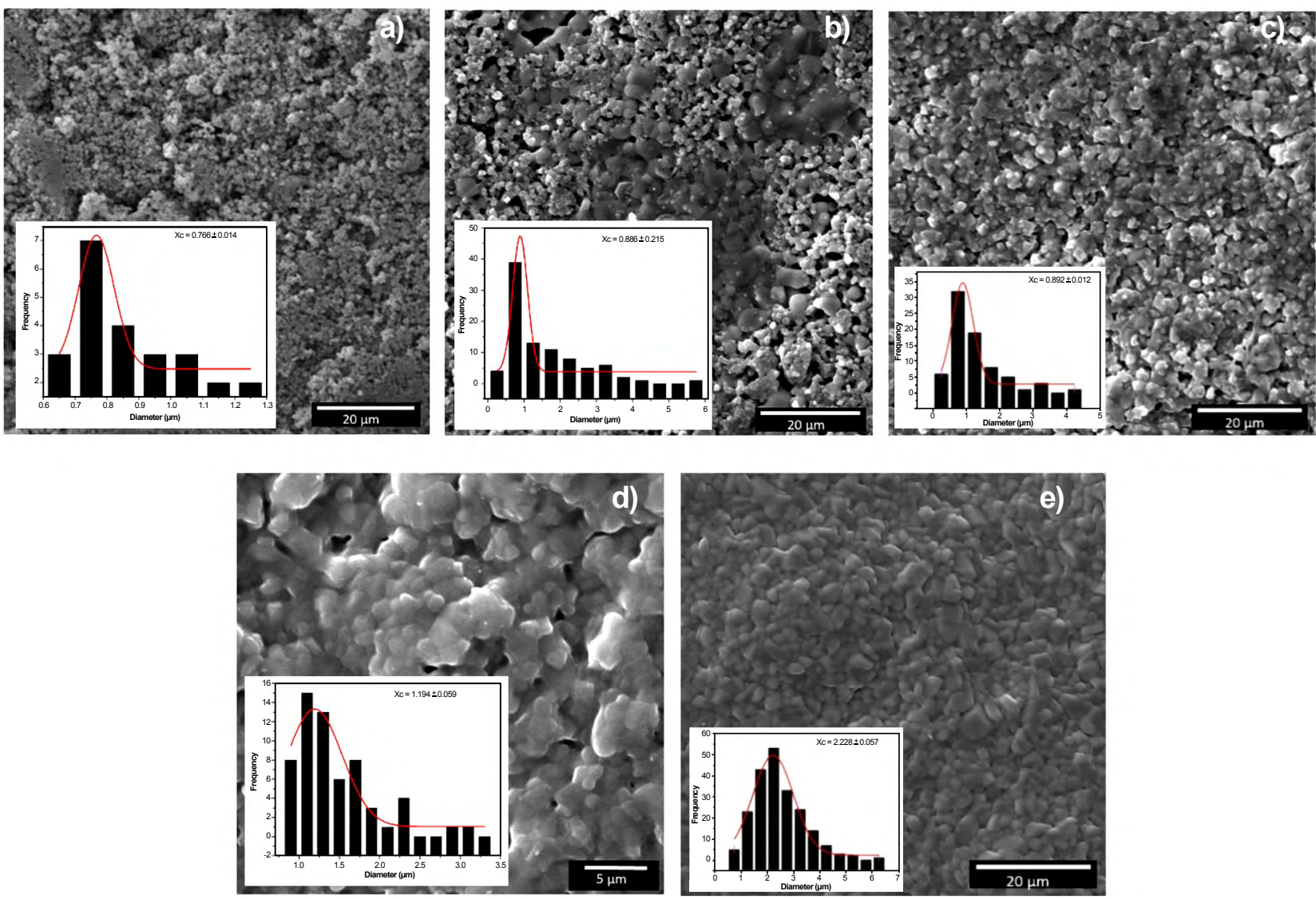

Figure 4: SEM micrographs of the BFO-BZN $\beta$ ceramic composite sintered at $1000{ }^{\circ} \mathrm{C} / 150$ min: a) BFO; b) BZN $\beta 75$; c) BZN $\beta 50$; d) BZN $\beta 25$; e) BZN $\beta$.

[Figura 4: Micrografias de MEV dos compósitos cerâmicos BFO-BZN $\beta$ sinterizados a $1000{ }^{\circ} \mathrm{C} / 150$ min: a) BFO; b) BZN $\beta 75$; c) BZN $\beta 50$; d) $B Z N \beta 25$; e) $B Z N \beta$.]

Table II - Elemental composition (at\%) of composites BFO-BZN $\alpha$ and BFO-BZN $\beta$.

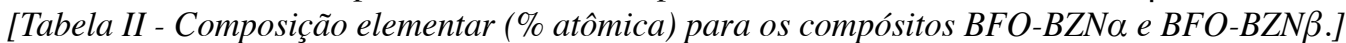

\begin{tabular}{cccccccccc}
\hline Element & BFO & BZN $\alpha 75$ & BZN $\alpha 50$ & BZN $\alpha 25$ & BZN $\alpha$ & BZN $\beta 75$ & BZN $\beta 50$ & BZN $\beta 25$ & BZN $\beta$ \\
\hline $\mathrm{O}$ & 9.1 & 15.7 & 27.6 & 32.2 & 33.2 & 15.9 & 29.0 & 33.8 & 33.4 \\
$\mathrm{Zn}$ & - & 3.0 & 4.3 & 5.7 & 6.7 & 1.6 & 3.2 & 0.95 & 4.6 \\
$\mathrm{Nb}$ & - & 7.1 & 11.1 & 16.8 & 19.0 & 6.1 & 5.6 & 14.1 & 16.5 \\
$\mathrm{Bi}$ & - & 15.5 & 23.5 & 32.3 & 35.7 & 17.6 & 18.3 & 15.6 & 41.9 \\
$\mathrm{Ba}$ & 14.1 & 8.0 & 4.6 & 2.5 & - & 9.0 & 24.5 & 39.0 & - \\
$\mathrm{Fe}$ & 71.3 & 43.2 & 21.9 & 9.3 & - & 45.2 & 10.8 & 2.1 & - \\
\hline
\end{tabular}

temperature, there is an increase in the diffusion rate and consequent increase in the reaction rate and reduction in the reaction time, generating higher amounts of $\beta$-BZN at $1000{ }^{\circ} \mathrm{C}$ in relation to the sample calcined at $700{ }^{\circ} \mathrm{C}[8]$. The formation of $\beta$-BZN at $1000{ }^{\circ} \mathrm{C}$ for $2 \mathrm{~h}$ of treatment was almost complete, with some $\mathrm{X}$-ray diffraction peaks characteristic of other remaining phases of the reaction mechanism, however, refinement indicated $100 \%$ of $\beta-\mathrm{BZN}$, establishing that at this temperature and treatment time an appreciable amount of this phase was obtained [8].

$\mathrm{Bi}_{5} \mathrm{Nb}_{3} \mathrm{O}_{15}+\mathrm{BiNbO}_{4}+2 \mathrm{ZnO} \rightarrow 3 \beta-\mathrm{BZN}$
Scanning electron microscopy (SEM): Figs. 3 and 4 show the obtained SEM images for the composites BFO$\mathrm{BZN} \alpha$ and $\mathrm{BFO}-\mathrm{BZN} \beta$, respectively, and the grain size distribution for all studied samples. As can be seen in Fig. 3 , the microstructures were formed by clusters of grains, originated from the sintering of the nanometer-sized particles during the heat treatment. The samples exhibited a dense microstructure showing grains and agglomerates of grains of various sizes, as well as a certain degree of porosity. These porous microstructures were derived from the synthesized powders having an unfavorable particle size distribution and aggregates (Figs. 3a and 3e). It was 
also observed a heterogeneous microstructure with grains larger than $0.6 \mu \mathrm{m}$ (generated from the coalescence of the particles of the agglomerated groups) mixed with smaller grains. The grain size distribution histograms (inserts in Fig. 3) showed that the mean grain size was between about 0.7 and $0.9 \mu \mathrm{m}$ for the BFO-BZN $\alpha$ ceramic composites. The $\mathrm{BFO}$ and $\mathrm{BZN} \alpha$ samples had an average grain size of $\sim 0.77$ and $\sim 1.7 \mu \mathrm{m}$, respectively. The microstructures of the BFOBZN $\beta$ composites (Fig. 4) were also formed by agglomerated grains originating from the sintering of nanosized particles during the heat treatment. The samples exhibited a dense microstructure, with elongated and hexagonal grains, of different sizes (insets in Fig. 4). A heterogeneous microstructure with grains larger than $0.7 \mu \mathrm{m}$ (generated from the coalescence of the particles of the agglomerated groups) mixed with smaller grains was also observed. The grain size distribution histograms (insets in Fig. 4) showed that the mean particle size was between about 0.9 and $1.2 \mu \mathrm{m}$ for the BFO-BZN $\beta$ ceramic composites. The BFO and BZN $\beta$ samples had a mean particle size of $\sim 0.77$ and $\sim 2.3 \mu \mathrm{m}$, respectively. Compared to BFO-BZN $\alpha$ composites, BFOBZN $\beta$ composites exhibited lower porosity. The results of the EDS (energy dispersive spectroscopy) analyzes for the BFO-BZN $\alpha$ and BFO-BZN $\beta$ composites are shown in Table II.

\section{CONCLUSIONS}

The synthesis of the BFO-BZN $\alpha$ and BFO-BZN $\beta$ composites by the ceramic method was satisfactory, since the microstructures of the composites presented grains with sizes between 0.6-0.9 $\mu \mathrm{m}$ and 0.9-1.2 $\mu \mathrm{m}$, respectively, close to the grain sizes obtained by other synthesis methods. The composites presented a compact and heterogeneous microstructure, indicating that the temperature used for sintering $\left(1000{ }^{\circ} \mathrm{C} / 150 \mathrm{~min}\right)$ was adequate for obtaining the ceramic composites; the composite BFO-BZN $\beta$ was less porous than the composite BFO-BZN $\alpha$. The XRD patterns of samples $\mathrm{BZN} \alpha$ and $\mathrm{BZN} \beta$ showed the presence of second-phases, indicating that the calcination at $700{ }^{\circ} \mathrm{C} / 2 \mathrm{~h}$ was insufficient to obtain the pure phases of these materials.

\section{REFERENCES}

[1] A.J. Moulson, J.M. Herbert, Electroceramics: materials, properties, applications, John Wiley, London (2003) 576.

[2] J.E.V. de Morais, A.J.N. de Castro, R.G.M. Oliveira, F.F. do Carmo, A.J.M. Sales, J.C. Sales, M.A.S. Silva, D.X. Gouveia, M.M. Costa, A.R. Rodrigues, A.S.B. Sombra, J.
Electron. Mater. 47, 7 (2018) 3829.

[3] J.J. Heremans, J. Zhong, R. Varghese, G.T. Yee, S. Priya, in Advances and applications in electroceramics, K.M. Nair, Q. Jia, S. Priya (Eds.), John Wiley, Hoboken (2011) 211.

[4] M.W. Barsoum, Fundamentals of ceramics, Inst. Physics, Bristol (2002) 494.

[5] F.M.M. Pereira, M.R.P. Santos, R.S.T.M. Sohn, J.S. Almeida, A.M.L. Medeiros, M.M. Costa, A.S.B. Sombra, J. Mater. Sci. 20, 5 (2009) 408.

[6] H. Wang, X. Yao, in Handbook of advanced dielectric, piezoelectric and ferroelectric materials: synthesis, properties and applications, Z. Ye (Ed.), CRC Press, New York (2008) 503.

[7] E.A. Nenasheva, N.F. Kartenko, J. Eur. Ceram. Soc. 21, 15 (2001) 2697.

[8] F.W.C. Farias, A.S.G. Alves, Y.M.S. Alves, F.M.M. Pereira, M.D.B. Barroso, J.C. Sales, A.S.B. Sombra, Mater. Sci. Forum 912 (2018) 16.

[9] Y.M.S. Alves, C.H.A. Pereira, F.W.C. Farias, F.M.M. Pereira, M.D.B. Barroso, J.C. Sales, A.S.B. Mater. Sci. Forum 912 (2018) 21.

[10] F.M.M. Pereira, C.A.R. Junior, M.R.P. Santos, R.S.T.M. Sohn, F.N.A. Freire, J.M. Sasaki, J.A.C. de Paiva, A.S.B. Sombra, J. Mater. Sci. 19, 7 (2008) 627.

[11] S. Ram, K. Ram, Infrared Phys. Technol. 37, 4 (1996) 457.

[12] Ph. Colomban, G. Lucazeau, J. Chem. Phys. 72, 2 (1980) 1213.

[13] S. Ram, Phys. Rev. 51, 10 (1995) 6280.

[14] J. Huang, H. Zhuang, W. Li, Mater. Res. Bull. 38, 1 (2003) 149.

[15] H.A. Elkady, M.M. Abou-Sekkina, K. Nagorny, Hyperfine Interact. 128, 4 (2000) 423.

[16] M.Y. Salunkhe, D.S. Choudhary, D.K. Kulkarni, Vib. Spectrosc. 34, 2 (2004) 221.

[17] J. Kreisel, G. Lucazeau, H. Vincent, J. Solid State Chem. 137, 1 (1998) 127.

[18] M.P. Chon, K.B. Tan, C.C. Khaw, Z. Zainal, Y.H. Taufiq-Yap, P.Y. Tan, Ceram. Int. 38, 5 (2012) 4253.

[19] S.M. Zanetti, S.A. Silva, Mater. Res. 10, 3 (2007) 261.

[20] H. Du, X. Yao, L. Zhang, Ceram. Int. 28, 3 (2002) 231.

[21] J.C. Nino, M.T. Lanagan, C.A. Randall, Appl. Phys. Lett. 81, 23 (2002) 4404.

[22] B.J. Kennedy, Physica B 241-243 (1998) 303.

[23] M. Chen, D.B. Tanner, J.C. Nino, Phys. Rev. B 72, 5 (2005) 54303.

[24] J.C. Nino, M.T. Lanagan, C.A. Randall, J. Mater. Res. 16, 5 (2001) 1460.

(Rec. 19/05/2019, Rev. 25/06/2019, Ac. 17/07/2019) 